\title{
Unilateral Bleeding Polyp in a Child: Lobular Capillary Hemangioma
}

\author{
Darwin Kaushal ${ }^{1}$, Rahul Kr. Singh ${ }^{1}$, Sourabha K Patro ${ }^{1 *}$, Aasma Nalwa ${ }^{2}$ and Deepak Vedant ${ }^{2}$ \\ ${ }^{1}$ Department of Otolaryngology and Head and Neck Surgery, All India Institute of Medical Sciences, India \\ ${ }^{2}$ Department of Pathology, All India Institute of Medical Sciences, India
}

Submission: September 22, 2017; Published: January 25, 2018

*Corresponding author: Sourabha Kumar Patro, Assistant Professor, Department of Otolaryngology \& Head and Neck Surgery, All India Institute of Medical Sciences, Jodhpur-342005, Rajasthan, India, Email: sourabhlipi@gmail.com

\begin{abstract}
Epistaxis, though being common, always attracts special attention from medical professionals due to the nature of bleeding involved in the process. Children presenting with unilateral epistaxis warn otolaryngologists as the cause can vary from nasal foreign bodies to life threatening hemangiomas and angiofibromas. We present a rare case of lobular capillary hemangioma originating from nasal septum in a child who presented with episodes of profuse bleed. Early diagnosis and management with total excision was awarding. The occurrence is rare, however it should be in the differential diagnoses of unilateral nasal bleed in outpatient and emergency settings and strong suspicion is warranted.
\end{abstract}

Keywords: Unilateral bleeding polyp in children; Nasal bleeding polyp; Unilateral nasal bleed; Lobular capillary hemangioma; Hemangioma of nose; Unilateral epistaxis

\section{Introduction}

Lobular capillary hemangioma ( $\mathrm{LCH})$ is an acquired benign vascular proliferation of unknown origin, which was first described as human botromycosis by Poncet and Dor in 1897 [1]. Skin of head and neck and mucos membrane of the oral cavity are common sites but LCH is rare in the nasal cavity of children. The nasal septum is the most common affected nasal site, vestibule and middle turbinate being the other involved sites [2,3]. We present a case of lobular capillary hemangioma in a nine year old child who had presented with unilateral nasal bleed.

\section{Case Report}

A nine year old child presented to the outpatient department of otolaryngology and head and neck surgery with 5 months history of recurrent nasal bleeding from left nasal cavity and left sided nasal obstruction. History of frequent nose picking present. On anterior rhinoscopy, single red fleshy lobulated mass of size $1.5 \times 1.5 \mathrm{~cm}$ was present in the left nasal cavity surrounded with blood clot. Contrast enhanced Computed tomography (CECT) of Paranasal sinus revealed a heterogeneously enhancing soft tissue lesion attached to the cartilaginous part of nasal septum (Figure 1). Rest of the head and neck and systemic examination was normal. Hence provisional diagnosis of a vascular nasal mass was made. Patient was planned for endoscopic excision under general anesthesia.

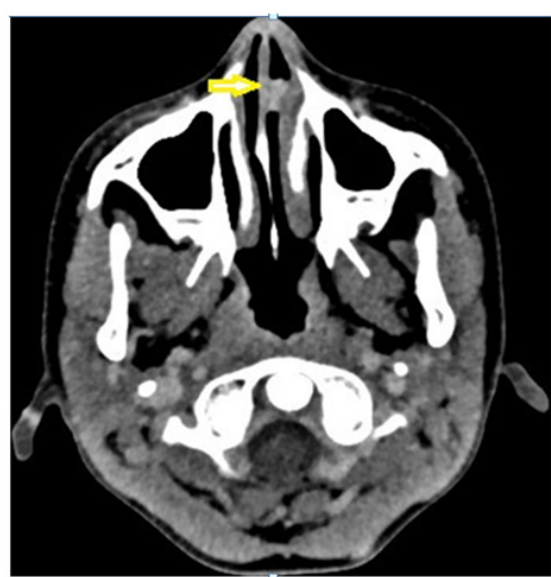

Figure 1: Hetrogeneously enhancing soft tissue lesion (arrowed).

Under general anaesthesia, after decongestion of bilateral nasal cavity, evaluation of the nasal mass was done. Endoscopic evaluation revealed a pinkish nasal mass which was arising from the cartilaginous part of the nasal septum (Figure 2). Stalk of the nasal mass was cauterized with bipolar cautery and the tumour was removed into to with sacrifice of $0.5 \mathrm{~cm}$ surrounding mucosa at the site of attachment of the lesion. Adequate haemostasis was achieved. Anterior nasal packing was done. 
Anterior nasal packs were removed after 24 hours and patient was discharged. The follow up of the patient was uneventful. Histopathological examination revealed the diagnosis of lobular capillary hemangioma. Microscopic examination showed biopsy tissue lined by focally ulcerated stratified squamous epithelium with underlying lobular arrangement of capillaries surrounding a large central vessel. The lumen of these capillaries varied from barely visible to large vascular spaces. The spindle shaped pericytic cells were seen in the periphery. No atypical mitotic figure or evidence of necrosis (Figure $3 \& 4$ ).

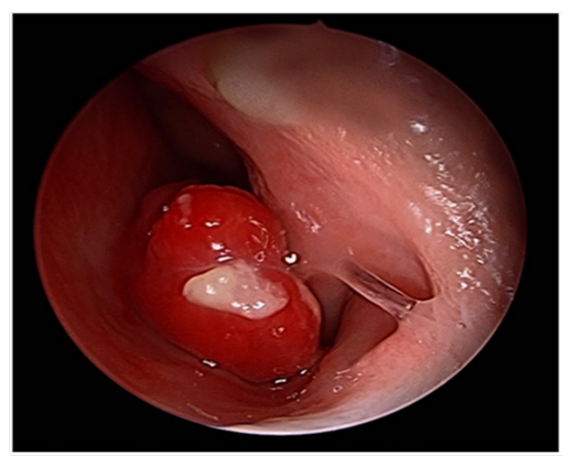

Figure 2: Reddish left nasal mass seen during endoscopy.

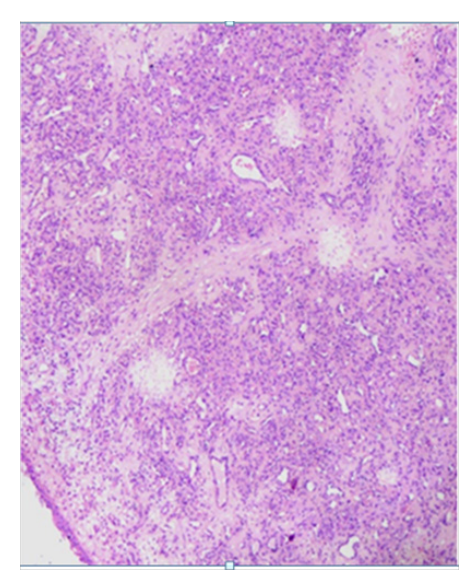

Figure 3: Characteristic lobular arrangement of capillaries with surrounding pericytic cells. (H.E. original magnification $4 \mathrm{x}$ ).

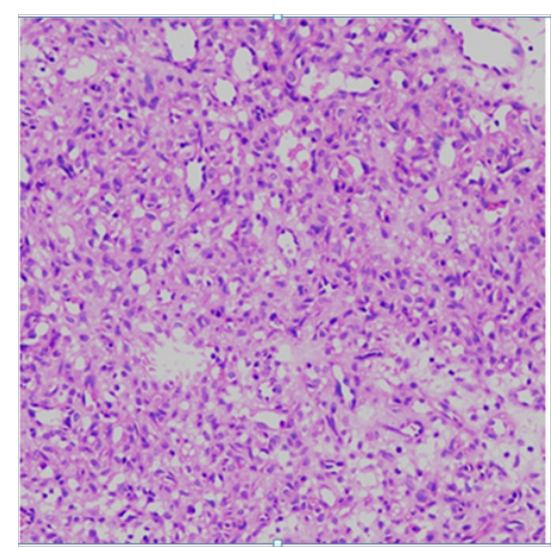

Figure 4: Capillaries have barely visible lumina to some large vascular spaces. (H.E. original magnification 10x).

\section{Discussion}

Lobular capillary hemangioma (LCH) was thought as pyogenic granuloma in earlier times but later denoted as misnomer because of non-infectious and non granulomatous nature. Present terminology of LCH is based on the characteristic histopathological findings described by Miller [4].

Incidence of LCH is more in females as compared to males and is common in third decade of life [5]. Nasal cavity is an unusual site for LCH. Gingiva is a common site of lobular capillary hemangioma. Among the nasal sites, anterior septal mucosa and tip of turbinate's are the most frequent involved sites [1]. The presented case is that of a 9 year old male child who presented with a bleeding polypus of the anterior nasal cavity and which turned out to be LCH. The lesion in this case was found to be attached to the septal cartilage.

Natural history and progression of LCH involves many contributing factors. These include trauma, hormonal imbalances, viral oncogenes, arterioveno malformation and angiogenic growth factors etc [6]. This child had a history of frequent nasal pricking, which could have led to repeated microtrauma and proliferation of vessels to form LCH attached to the nasal septum anteriorly. LCH have also been described as pregnancy tumour [7] due to increased associations with high levels of estrogen and progesterone during pregnancy.

LCH usually presents with various symptoms such as unilateral epistaxis, nasal obstruction, nasal discharge, facial pain, headache etc depending on the site of lesion [6]. This patient had presented to our OPD with repeated episodes of left sided nasal bleed especially after nose pricking. Father of the child had noticed a small red mass in the left nasal cavity for which he brought the child into our outpatient department.

CECT of the nose and paranasal sinuses is the preferred investigation for diagnosis of vascular lesions. Magnetic Resonance Imaging (MRI) with T2 weighted images reveal vascular soft tissue lesions with multiple flow voids [8].

Criterion standard treatment in LCH has always been complete surgical excision of the lesion. Surgical technique and instrumentation used for such kind of lesions include cold instrumentation (with or without preoperative embolization), electrocoagulation, cryotherapy and LASER [9]. We did endoscopic excision of the hemangioma followed by cauterization of its base at the nasal septum which had the feeding vessels in it.

Recurrences of the lobular capillary hemangioma are a rare occurrence. However, evidence in literature report a recurrence rate of 0 to $42 \%$ depending on the location, extent of removal and time of follow up [10]. This case has been followed up for 4 months till date and there is no evidence of recurrence of the lesion. 


\section{Conclusion}

Lobular capillary hemangioma of the nasal cavity is a rare entity especially in a male child in first decade of life. However, it should be considered as one of the differential diagnoses of unilateral epistaxis in children. High index of suspicion is the key for identifying such a lesion. Endoscopy guided complete surgical excision of the lesion is the management of choice for nasal lesions. Recurrence is rare with no malignant transformation reported till date.

\section{References}

1. Akyol MU, Yalciner EG, Dogan AI (2001) Pyogenic granuloma (lobular capillary hemangioma) of the tongue. Int J Pediatr Otorhinolaryngol 58(3): 239-241.

2. Katori H, Tsukuda M (2005) Lobular capillary hemangioma of the nasal cavity in child. Auris Nasus Larynx 32(2): 185-188.

3. Kurtaran H, Uraldi C, Ark N, Aktas D (2006) Lobular capillary haemangioma of the middle turbinate. Acta Otolaryngol 126(4): 442444

4. Miller FR, D'Agostino MA, Schlack K (1999) Lobular capillary hemangioma of the nasal cavity. Otolaryngology-head and neck surgery 120(5): 783-784.

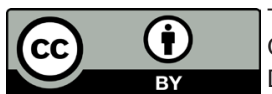

This work is licensed under Creative Commons Attribution 4.0 Licens

DOI: 10.19080/JHNSS.2018.02.555580
5. Ozcan C, Apa DD, Gorur K (2004) Pediatric lobular capillary hemangioma of the nasal cavity. Eur Arch Otorhinolaryngol 261(8): 449-451.

6. Genc S, Kürkçüoğlu ŞS, Karabulut H, Acar B, Tunçel Ü, et al. (2009) Giant lobular capillary hemangioma of the nasal septum. Turkish Journal of Medical Sciences 39(2): 325-328.

7. Delbrouck C, Chamiec M, Hassid S, Ghanooni R (2011) Lobular capillary haemangioma of the nasal cavity during pregnancy. J Laryngol Otol 125(9): 973-977.

8. Yang BT, Li SP, Wang YZ, Dong JY, Wang ZC (2013) Routine and dynamic MR imaging study of lobular capillary hemangioma of the nasal cavity with comparison to inverting papilloma. AJNR Am J Neuroradiol 34(11): 2202-2207.

9. el-Sayed Y, al-Serhani A (1997) Lobular capillary haemangioma (pyogenic granuloma) of the nose. J Laryngol Otol 111(10): 941-945.

10. Smith SC, Patel RM, Lucas DR, McHugh JB (2013) Sinonasal lobular capillary hemangioma: a clinicopathologic study of 34 cases characterizing potential for local recurrence. Head Neck Pathol 7(2): 129-134.

\section{Your next submission with Juniper Publishers will reach you the below assets}

- Quality Editorial service

- Swift Peer Review

- Reprints availability

- E-prints Service

- Manuscript Podcast for convenient understanding

- Global attainment for your research

- Manuscript accessibility in different formats

( Pdf, E-pub, Full Text, Audio)

- Unceasing customer service

Track the below URL for one-step submission https://juniperpublishers.com/online-submission.php 